\title{
A case Study on wired and Wireless charger standards in India for Electric Vehicle Application
}

\author{
Shivanand $M N^{1}$, Y. Maruthi ${ }^{1}$ Phaneendra Babu Bobba ${ }^{2}$, Sandeep Vuddanti ${ }^{1}$ \\ ${ }^{1}$ GRIET, EEE Department, Hyderabad, Telangana, India \\ ${ }^{2}$ CUK, Electrical Engineering Department, Kalburgi, Karnataka, India
}

\begin{abstract}
India has taken major step in adopting the electric vehicle by means of FAME Scheme (Fast Adoption and Manufacturing of Electric Vehicles), a government initiative. ARAI (Automotive Research Authority of India) and DHI (Department of Heavy Industry) have published standardization protocol for both EV charging infrastructure. Many of those standards are derived from the SAE (Society of Automotive Engineers) Internationals and IEC (International Electrotechnical Commission). USA, Europe and China are also following the same standards to build the EV (Electric Vehicle) infrastructure. This paper provides the Indian standards to build EV charging infrastructure and comparing it with other countries. Glimpses on energy demand for electric vehicles in Indian market. It also provides the demanding wireless power transfer technology in EV's. Status of Standards provided by the industry on wireless power transfer. Factors that are necessary to be considered before drafting the standards for WPT.
\end{abstract}

\section{India's Charging Infrastructure}

India aims to have at least 15 percent of the vehicles on its roads to be electric in five years, signalling the government's wish to join a long list of countries around the world that are already seeking to cut fossil fuels aggressively. While cumulative global sales of passenger electric vehicles likely surpassed 4 million in August, with China accounting for more than a third since 2011, India sold an estimated 2,000 EVs 2017. EVs may account for about 7 percent of sales in India by 2030 by [1]. The government of India (Department of Heavy Industries - DHI) is already providing incentives through FAME scheme (Faster Adoption and Manufacturing of Electric Vehicles) from the year 2015 in order to reduce the price of EV's. The government has also approved pilot projects, charging infrastructure projects and technological development projects. Energy Efficiency Services Limited (EESL), under the administration of Ministry of Power, Government of India (GoI), has ordered 10,000 EVs [2]. With all the initiation that India has been taking, there is serious issue of charging infrastructure for both wired and wireless charging system. Standardization to the technical aspects of the EVs charging, range and price are the major barrier for deployment. Currently in India, there are very small scale of AC and DC charging stations available, which are installed by EV manufacturers. Even though the $\mathrm{AC}$ slow charging infrastructure at residences, workplaces and public places requires very low investment when compared to fuel stations. Still, the EV charging infrastructure growth in India is not up to the mark. To grow large scale of charging infrastructure in
India it requires continuous support from the government, utility grid authorities and automobiles manufacturers.

\subsection{Indian EV Charging Standards}

Departemnt of Heavy Industry (DHI) \& Automotive Research Association of India (ARAI) drafted industry standard for Electric Vehicle Charging infrastructure on December 2015. The first draft of AC-charging configurations are Type-I and Type-II. Type-III standards are published in the second draft on May 2017. [3]

\subsubsection{Type-I: AC001 $(3.3 \mathrm{KW}, 15 \mathrm{~A}, 230 \mathrm{~V})$}

- Derived from IEC 60309 Standard

- AC Slow charging

- Each outlet will have up to three independent charging sockets.

- Input: 3 phase AC Supply, 5 wire (3 phase+ Neutral + PE- Protective Earth). Nominal Input Voltage is $415 \mathrm{~V}$ $(+6 \%$ and $-10 \%)$ as per IS 12360

- Frequency is $50 \mathrm{~Hz} \pm 1.5 \mathrm{~Hz}$

- Output: Single phase, two wire system $230 \mathrm{~V}$ ( $+6 \%$ or 10\%) and 15 Amps as per IS12360

- No Communication protocol is used between EV and EVSE (EV Supply Equipment)

\subsubsection{Type-II: AC001(>3.3KW)}

\footnotetext{
* Corresponding author: shivanandnaduvin@gmail.com
} 
- Charger power is greater than $3.3 \mathrm{KW}$.

- This AC Fast charging.

- Outlet is derived from the Standard IEC 62196 and IEC 61851.

- Charging with $415 \mathrm{~V}$, three phases, 63A.

- Control Pilot (communication protocol) extends to control EV charging Equipment system (EVSE).

\subsubsection{Type-III: DC001(48V/2V,10KW/15KW)}

- Input: 3 phase AC Supply, 5 wire (3phases+N+PE). Nominal Input Voltage is $415 \mathrm{~V} \&$ frequency is $50 \mathrm{~Hz} \pm$ $1.5 \mathrm{~Hz}(+6 \%$ and $-10 \%)$ Maximum 200 Amps as per IS 12360.

- Output- $48 \mathrm{~V}$ or $72 \mathrm{~V} \mathrm{DC}$, based on suitable charger Configuration for vehicle battery.

- Charger Configuration Types

- Single Vehicle charging at $48 \mathrm{~V} / 72 \mathrm{~V}$ with a maximum of $10 \mathrm{~kW}$, or a 2 Wheel vehicle charging at $48 \mathrm{~V}$ with maximum $3.3 \mathrm{~kW}$.

- Single Vehicle charging at $48 \mathrm{~V}$ with a maximum of $10 \mathrm{KW}$, or $72 \mathrm{~V}$ with maximum $15 \mathrm{~kW}$ or a 2 Wheel vehicle charging at $48 \mathrm{~V}$ with maximum $3.3 \mathrm{~kW}$.

\subsection{Charging System Available in The World}

\subsubsection{The International Electrotechnical Commission (IEC 62196) modes definition:}

Mode-1: Slow charging from a regular electrical socket (single or three phase)

Mode-2: Slow charging from a regular socket but which equipped with some EV specific protection arrangement Mode-3: Slow or Fast charger using a specific EV multiPin Socket with control and protection functions

Mode-4: Fast charging using some specific charger technology such as CHAdeMO. [4]

\subsubsection{European EV Standards}

- Normal power or Slow Charging with rated power inferior to $3.7 \mathrm{~kW}$ is used for domestic application or for long-time EV parking.

- Medium power or quick charging with a rated power from $3.7-22 \mathrm{~kW}$ is used for private and public EV

- High power or fast charging with a rated power superior to $22 \mathrm{~kW}$ is used for public EV [4]

\subsubsection{American EV Standards}

TYPE-1: The charger is on-board and provides an AC voltage at 120 or 240 volts with a maximum current of $15 \mathrm{~A}$ and a maximum power of $3.3 \mathrm{~kW}$

TYPE-2: The charger is on-board and provides an $\mathrm{AC}$ voltage at $240 \mathrm{~V}$ with a maximum current of $60 \mathrm{~A}$ and a maximum power of $14.4 \mathrm{~kW}$.
TYPE-3: The charger is off-board, so the charging station provides DC voltage directly to the battery via DC connector with maximum power of $240 \mathrm{~kW}$. [4]

Table 1. Electrical Rating of Different Charge Method in North-America

\begin{tabular}{|c|c|c|c|}
\hline $\begin{array}{c}\text { Charging - } \\
\text { Method }\end{array}$ & AC Level 1 & AC Level 2 & DC Level 3 \\
\hline $\begin{array}{c}\text { Nominal } \\
\text { Supply } \\
\text { Voltage(V) }\end{array}$ & 120 & 240 & $207-600$ \\
\hline $\begin{array}{c}\text { Max. } \\
\text { Current (A) }\end{array}$ & 12 & 32 & 400 \\
\hline $\begin{array}{c}\text { Max. Power } \\
\text { (KW) }\end{array}$ & 1.44 & 7.7 & 240 \\
\hline $\begin{array}{c}\text { Charger } \\
\text { Location }\end{array}$ & $\begin{array}{c}\text { On-Board } \\
\text { 1-Phase }\end{array}$ & $\begin{array}{c}\text { On-Board } \\
\text { 1-Phase }\end{array}$ & $\begin{array}{c}\text { Off-Board } \\
3-P h a s e\end{array}$ \\
\hline $\begin{array}{c}\text { Communica } \\
\text { tion } \\
\text { Protocol }\end{array}$ & $\begin{array}{c}\text { Control Pilot } \\
\text { (CP) }\end{array}$ & CP & $\begin{array}{c}\text { Power Line } \\
\text { Carrier (PLC) }\end{array}$ \\
\hline
\end{tabular}

\subsubsection{EV charging based on Power and Usage Location}

Charging ratings of different electric vehicles based on their usage are classified from normal power rating of $3.7 \mathrm{~kW}$ to $>22 \mathrm{~kW}$.

Table 2. Classification of EV charging based on Power and Usage Location.

\begin{tabular}{|c|c|c|c|c|}
\hline $\begin{array}{c}\text { Charging } \\
\text { Method }\end{array}$ & $\begin{array}{c}\text { Connecti } \\
\text { on Type }\end{array}$ & $\begin{array}{c}\text { Power } \\
\text { (kW) }\end{array}$ & $\begin{array}{c}\text { Max. } \\
\text { Current } \\
\text { (A) }\end{array}$ & Location \\
\hline $\begin{array}{c}\text { Normal } \\
\text { Power }\end{array}$ & $\begin{array}{c}\text { I-Phase } \\
\text { AC }\end{array}$ & 3.7 & $10-16$ & Domestic \\
\hline $\begin{array}{c}\text { Medium } \\
\text { Power }\end{array}$ & $\begin{array}{c}\text { I or } 3 \\
\text { Phase }\end{array}$ & $3.7-22$ & $16-32$ & $\begin{array}{c}\text { Semi- } \\
\text { Domestic }\end{array}$ \\
\hline $\begin{array}{c}\text { High } \\
\text { Power }\end{array}$ & $\begin{array}{c}\text { 3- Phase } \\
\text { AC }\end{array}$ & $>22$ & $>32$ & Public \\
\hline $\begin{array}{c}\text { High } \\
\text { Power DC }\end{array}$ & DC & $>22$ & $>32$ & Public \\
\hline
\end{tabular}

\section{Electric Vehicles in India}

\subsection{Energy Demand for EV}

Energy required by utility grid increases as demand in the electric vehicle market. The automobiles production in India is at a CAGR of 5.81\% from 2007 to 2018 . The vehicles include $80.9 \%$ of two wheelers, $13.2 \%$ of passenger cars, $2.5 \%$ of three wheelers \& $3.4 \%$ of commercial vehicles [5]. Out of these, close to $99.9 \%$ are conventional ICE vehicles which are burning petrol\& 
diesel for traction. The figure 1 shows the historical vehicle production data along with the estimated production volumes by 2030 which is indicated with blue line and also it shows the historical \& estimated fuel (both petrol \& diesel) consumption in MMT (Million Metric Tonnes) which is indicated with red line.

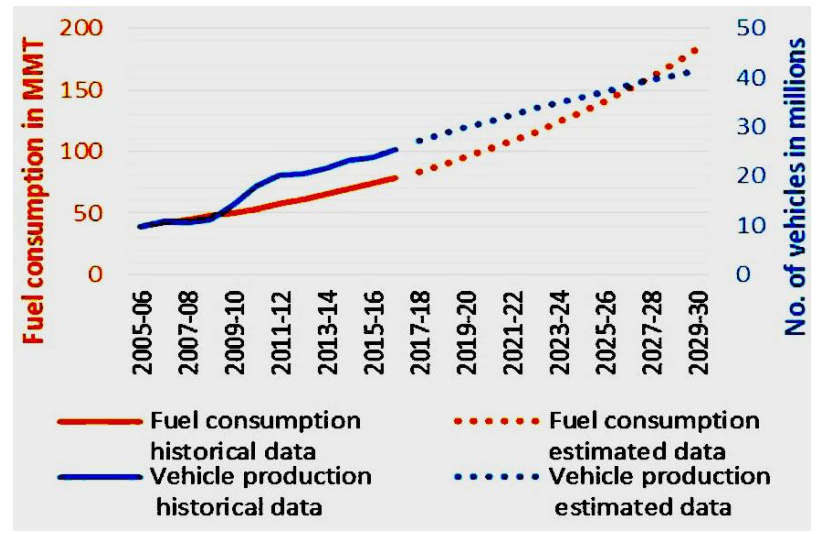

Fig. 1 Fuel Consumption \& Vehicle Production Data

The total electricity generation in India during the year 2016-17 is 1160TWh which is used in domestic, commercial, industrial \& agriculture sectors. The total electricity required, if all the existing ICE vehicles are converted into BEV's during the year 2016-17 is 439TWh which is $34.26 \%$ additional to the existing electricity generation. By 2030, the electricity generation (Egen) in India will grow along with the demand in the domestic, commercial, industrial \& agriculture sectors which is shown in the figure 3 (indicated with blue). Apart from this, there will be a growth in the production of automobiles in India by 2030 and if all these vehicles are $100 \%$ BEV's the required electricity generation (Egen tr) demand on the utility grid increases which is also shown in the figure 3 (indicated with red).

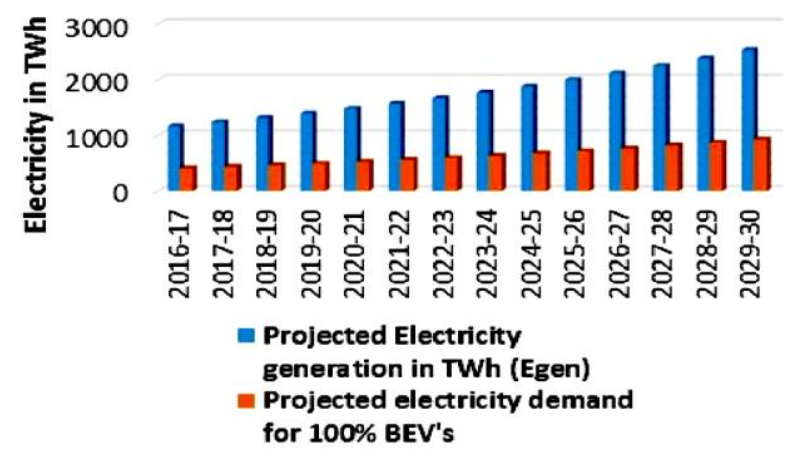

Fig. 2 Projected Electricity demand upto 2030

Hence by 2030 in India, 100\% of BEV's would require an energy of $929.3 \mathrm{TWh}$ which is about $37 \%$ additional electricity to be produced apart from estimated electricity generation of $2500 \mathrm{TWh}$ (includes domestic, commercial, agriculture \& industrial sectors etc.) [6].

\subsection{Indian Automobile Industry - An Overview}

The Indian Automobile Industry is currently ranked 5th largest in the world and is set to be the 3rd largest by 2030. The requirement of mobility in India is set to change dramatically in the near future to cater to the requirement of 1.30 billion population While there is a vision for $100 \%$ electric vehicles by 2030 , most industry experts indicate that around $40-45 \% \mathrm{EV}$ conversion by 2030 is a realistic expectation. A major push towards EVs will be led by the public transportation requirements in India - Fleet cars, E-Buses, 3 wheelers and 2 wheelers. Personal vehicle options for EVs will still be a relatively smaller element in the whole pie. The Government plans to work towards creating a demand for EVs by buying in bulk, which could provide for large orders for automakers. A tender for 10,000 cars is already issued and now a major tender for electric buses in 11 cities is likely to be released soon. [7]

\subsection{The outlook for 2018}

-Passenger cars to see a higher increase in new model launches compared to utility vehicles.

-Production capacity will also be added at car makers to reduce waiting periods and to boost demand. (Passenger vehicle segment growing between 7-9\%).

-In the two-wheeler segment, motorcycles are expected to grow moderately while scooters will continue to grow in double digits with two-wheelers growing between 9$11 \%$ in FY' 18.

-Industry moving towards a March 2020 launch of BS-6 and most OEM/Auto component firms have made investments to meet this deadline.

\subsection{EV Chargers}

\subsubsection{EV Chargers in India}

Post FAME and the Niti Ayog Plan announcement, we have seen an increased trust on setting up EV chargers in India. Some names we could confirm, who have joined interest in EV Chargers manufacturing are Raychem RPG India, Analogic India, Deltron, EOS Power, AdorPowertron, Kraft Power Con, Elind etc.

\subsubsection{Global EV Charger firms on Indian Market}

More than six key global firms eyeing the EV Chargers market closely. Firms like ABB India, Delta India, Schneider India, Siemens India etc are looking at the Indian market closely. These firms have their global designs and products. They are studying the technical/specifications, business models and potential for their products. All these firms are only looking at the 4 Wheelers' (Cars) EV Chargers. 
Table 3: Total number of EV Charging Stations in India

\begin{tabular}{|c|c|c|c|}
\hline Title & $\begin{array}{c}\text { Installed } \\
\text { base } \\
\mathbf{2 0 1 6 - 1 7}\end{array}$ & $\begin{array}{c}\text { Additions } \\
\text { in the last } \\
\text { 4 months }\end{array}$ & $\begin{array}{c}\text { Total } \\
\text { installed } \\
\text { base as of } \\
\text { August 2017 }\end{array}$ \\
\hline $\begin{array}{c}\text { EV Charging } \\
\text { stations }\end{array}$ & 100 & 30 & 130 \\
\hline $\begin{array}{c}\text { Average Norms of } \\
\text { EV Chargers }\end{array}$ & 1.5 & 4 & - \\
\hline $\begin{array}{c}\text { Total EV } \\
\text { Chargers installed }\end{array}$ & 150 & 120 & 270 \\
\hline $\begin{array}{c}\text { \% of AC Slow } \\
\text { chargers }\end{array}$ & $100 \%$ & $80 \%$ & $\mathrm{x}$ \\
\hline $\begin{array}{c}\text { \% of DC Fast } \\
\text { Chargers }\end{array}$ & $0 \%$ & $20 \%$ & $\mathrm{x}$ \\
\hline $\begin{array}{c}\text { No of AC Slow } \\
\text { chargers installed }\end{array}$ & 150 & 96 & 246 \\
\hline $\begin{array}{c}\text { No of DC Fast } \\
\text { Chargers installed }\end{array}$ & 0 & 24 & 24 \\
\hline
\end{tabular}

Table 4: Likely future market for EV Chargers in India

\begin{tabular}{|c|c|c|c|c|c|}
\hline Title & $\begin{array}{c}2017 \\
-18\end{array}$ & $\begin{array}{c}2018- \\
19\end{array}$ & $\begin{array}{c}2019- \\
21\end{array}$ & $\begin{array}{l}2021- \\
25\end{array}$ & $\begin{array}{c}\text { Potential } \\
\text { up to } \\
2026\end{array}$ \\
\hline $\begin{array}{l}\text { No of EV } \\
\text { Charging } \\
\text { stations } \\
\text { likely to be } \\
\text { set up }\end{array}$ & 1000 & 5,000 & $\begin{array}{c}50,00 \\
0\end{array}$ & $\begin{array}{c}350,0 \\
00\end{array}$ & 406,000 \\
\hline $\begin{array}{c}\text { Total EV } \\
\text { Chargers } \\
\text { likely to } \\
\text { be installed }\end{array}$ & 4000 & 20,000 & $\begin{array}{c}300,0 \\
00\end{array}$ & $\begin{array}{c}2,100 \\
, 000\end{array}$ & $2,424,000$ \\
\hline $\begin{array}{l}\text { \% of AC } \\
\text { Slow } \\
\text { chargers } \\
\text { likely }\end{array}$ & $90 \%$ & $80 \%$ & $80 \%$ & $70 \%$ & $\mathrm{x}$ \\
\hline $\begin{array}{l}\% \text { of DC } \\
\text { Fast } \\
\text { Chargers } \\
\text { likely }\end{array}$ & $10 \%$ & $20 \%$ & $20 \%$ & $30 \%$ & $\mathrm{x}$ \\
\hline $\begin{array}{l}\text { No of AC } \\
\text { Slow } \\
\text { chargers } \\
\text { likely to be } \\
\text { installed }\end{array}$ & 3600 & 16000 & $\begin{array}{c}240,0 \\
00\end{array}$ & $\begin{array}{l}1,470 \\
, 000\end{array}$ & $1,729,600$ \\
\hline $\begin{array}{l}\text { No of Fast De } \\
\text { chargers }\end{array}$ & 400 & 4000 & $\begin{array}{c}60,00 \\
0\end{array}$ & $\begin{array}{c}630,0 \\
00\end{array}$ & 694,400 \\
\hline
\end{tabular}

\section{EV Wireless Charging Standards}

As the world is advancing towards the wireless charging from smaller biomedical application to the electric vehicle charging system. Standardization is the main barrier holding the commercialization of high-voltage and high-power WPT for EV charging. It includes safety criteria, efficiency, EM(Electromagnetic) limits, and interoperability targets, along with test setup for getting wireless charging. It should provide the compatible charging station to all the EV owners. IEC-61980-1 standard contains the total system of WPT from supply network to EVs charging the battery or any equipment of the same at the standard supply of 1000 -Vac or 1500Vdc. These all are addressed by SAE in its standard SAE TIR J2954 (TIR-Technical Information Report). This is the first standard developed by SAE in WPT for an EV charging application. This standard is developed specifically for SWC. The frequency band, interoperability, safety, coil definitions, and EMC/EMF limits from SAE TIR J2954 allow any attuned vehicle to charge wirelessly from its wireless home charger, office or a commercial charger with the same charging ability. Table 5 shows key standards for wireless charging. [8] In the near term, vehicles that are capable to be charged wirelessly under recommended practice should also be able to be charged by SAE J1772 plug in chargers. SAE recommended practice $\mathrm{J} 2954$ is intended to be used for stationary applications (charging while vehicle is not in motion). Dynamic applications may be considered in the future based on industry feedback. SAE Recommended Practice J2954 is meant to be used for interoperability, performance and emissions testing, where a single standard coil-set has been chosen for the WPT Power Class 1 and 2 to $7.7 \mathrm{~kW}$, per Z-Classes (1 through 3) which is circular topology. However, there are two reference options for WPT 3 to $11 \mathrm{~kW}$ per Z-classes (1 through 3) with two topologies. The next revision of the Recommended Practice in 2018 is slated to have one standard coil set for WPT 3. SAE TIR J2954 establishes a common frequency band using $85 \mathrm{kHz}(81.39$ - 90 $\mathrm{kHz}$ ) for all light duty vehicle systems. [9]. 
Table 5: Wireless Charging standards

\begin{tabular}{|c|c|c|c|c|}
\hline $\begin{array}{l}\text { Standard } \\
\text { Developer }\end{array}$ & Standard Name & $\begin{array}{l}\text { Published/Update } \\
\text { Date }\end{array}$ & Description & Status \\
\hline IEC & $\begin{array}{l}\text { IEC } 6180-1 \mathrm{Ed} . \\
1.0 \text {-New } \\
\text { Addition }\end{array}$ & 2015-07-01 & $\begin{array}{l}\text { Electric Vehicle wireless power transfer (WPT) System- } \\
\text { Part 1: General Requirements }\end{array}$ & Active \\
\hline IEC & $\begin{array}{l}\text { IEC } 61980- \\
1 \mathrm{Ed} 2.0\end{array}$ & 2020-03-30 & $\begin{array}{l}\text { Electric Vehicle wireless power transfer (WPT) System- } \\
\text { Part 1: General Requirements }\end{array}$ & $\mathrm{ACD}$ \\
\hline IEC & $\begin{array}{l}\text { IEC } 61980- \\
\text { 1/IAMD I Ed1.0 }\end{array}$ & 2015-07-24 & $\begin{array}{l}\text { Electric Vehicle wireless power transfer (WPT) System- } \\
\text { Part 1: General Requirements }\end{array}$ & $\mathrm{ACD}$ \\
\hline IEC & $\begin{array}{l}\text { IEC } 61980- \\
1 / \text { COR1A }\end{array}$ & 2017-01-01 & $\begin{array}{l}\text { Electric Vehicle wireless power transfer (WPT) System- } \\
\text { Part 1: General Requirements }\end{array}$ & VALID \\
\hline IEC & $\begin{array}{l}\text { DRAFT } \\
\text { IEC/TS } 61980- \\
2 \text { Ed. } 1.0\end{array}$ & $\begin{array}{l}\text { Will be published } \\
\text { in } 2017\end{array}$ & $\begin{array}{l}\text { Electric Vehicle wireless power transfer (WPT) Systems- } \\
\text { part2: Specific Requirements for communication between } \\
\text { Electric Road Vehicle (EV) and Infrastructure concerning } \\
\text { Wireless power transfer (WPT) }\end{array}$ & Active \\
\hline IEC & $\begin{array}{l}\text { Draft } \\
\text { IEC/TS61980- } \\
\text { 3Ed1.0 }\end{array}$ & $2015-08-28$ & $\begin{array}{l}\text { Electric vehicle wireless power transfer (WPT) systems- } \\
\text { part3: Specific Requirements for the magnetic field power } \\
\text { transfer system }\end{array}$ & $\begin{array}{l}\text { Draft, } \\
\text { Valid }\end{array}$ \\
\hline SAE & J2954SAE & WIP & Wireless charging Electric and Plug in Hybrid vehicles & WIP \\
\hline SAE & J2954_201605 & 2016-05-26 & $\begin{array}{l}\text { Wireless power transfer for light duty plug in /Electric } \\
\text { vehicles and Alignment methodology }\end{array}$ & Issued \\
\hline SAE & J1773_201406 & 2014-06-05 & SAE electric Vehicles inductively coupled charging & Stabilized \\
\hline SAE & $\mathrm{J} 2847-6$ & 2015-08-05 & $\begin{array}{l}\text { Communication between Wireless charger charged } \\
\text { vehicles and wireless EV Chargers }\end{array}$ & Issued \\
\hline SAE & $\mathrm{J} 2831$ & $2015-8-27$ & $\begin{array}{l}\text { Signalling Communication for wireless charged Electric } \\
\text { vehicle }\end{array}$ & Issued \\
\hline UL & Subject 2750 & NA & $\begin{array}{l}\text { Outline of Investigation for Electric Vehicle wireless } \\
\text { charging }\end{array}$ & $\begin{array}{l}\text { Draft } \\
\text { Released }\end{array}$ \\
\hline
\end{tabular}

\section{CONCLUSION AND FUTURE WORK}

The major obstacle to the adaptation wireless EV's charging is the standardization. The inductive coupled power transfer has given greater results than the other types of system. The factors that needs standardization are geometry of coils, volume and weight, position of coil, alignment, frequency, compensation topologies, distance and Efficiency. Including the human and environmental consideration due to electromagnetic radiation. DHI and ARAI has provided standards for conductive charging infrastructure. The standards provided are very limited to the charging equipment and its features. But lacks in charging time, driving range, lack of awareness and efficiency. 


\section{References}

1 Bloomberg Technology https://www.bloomberg.com/news/articles/20 18-09-06/india-proposes-a-goal-of-15-electricvehicles-in-five-years

2 Energy Efficiency Services Ltd http://www.eeslindia.org/content/dam/doitassets/ee sl/pdf/Coffee\%20Table\%20Book/EESL_Book fin al.pdf

3 Department of Heavy Industry https://dhi.nic.in/UserView/index?mid=2418

4 M. C. Falvo, D. Sbordone, I. S. Bayram and M. Devetsikiotis, "EV charging stations and modes: International standards," Ischia, 1134-1139, 2014.

5 http://www.siamindia.com/statistics.aspx?mpgid= 8\&pgidtrail $=14$

6 S. Nair, N. Rao, S. Mishra and A. Patil, "India's charging infrastructure - biggest single point impediment in EV adaptation in India," Pune, $1-6,2017$

7 India EV Storyhttps://www.innovasjonnorge.no/contentasse ts/815ebd0568d4490aa91d0b2d5505abe4/ind ia-ev-story.pdf
8 A. Ahmad, M. S. Alam and R. Chabaan, "A Comprehensive Review of Wireless Charging Technologies for Electric Vehicles," 4, 38-63, 2018.

9 SAE International "Wireless Power Transfer for Light-Duty Plug-In/Electric Vehicles and Alignment Methodology" ,2017

10 Green Car Congress - Energy, Technology, issues and policies for sustainable mobility https://www.greencarcongress.com/2016/05/ 20160518-j2954.html 